\title{
University Graduates' Assessment of the Relevance of the Curriculum to the Labor Market in the Philippines
}

\author{
Cathy Mae D. Toquero (Corresponding author) \\ College of Education, Mindanao State University \\ General Santos City, Philippines
}

Tel: 63-955-448-1100Ｅ-mail: cathymaetoquero@gmail.com

Diane Mae P. Ulanday, EdD

College of Education, Mindanao State University

General Santos City, Philippines

Tel: 63-935-982-5862Ｅ-mail: dianemae.ulanday@msugensan.edu.ph

Received: July 10, 2020 Accepted: January 22, $2021 \quad$ Published: January 28, 2021

doi: 10.5296/ire.v9i1.17421 URL: https://doi.org/10.5296/ire.v9i1.17421

\begin{abstract}
A university with a relevant curriculum offers authentic practical work experience integrated in the subjects to capacitate the graduates to be job-ready to meet the demands of employers in the industry. In contrast, the graduates are confronted with numerous difficulties in finding a job with their acquired that lacks the required skills from degree curriculum. Based on graduates' self assessment report, this study described the match of the educational qualifications and relevance of the curriculum of the graduates to their current employment. A survey research design was used to gather the self-evaluated responses of 1761 individuals who graduated during 2012 to 2017 from the seven colleges of Mindanao State University-General Santos City (MSU-GSC), Philippines. Questionnaires were distributed for data collection through face-to-face and online data gathering. Results revealed that the supply of graduates' educational skills are highly matched with the skills demanded by the industry and that the curriculum is responsive to the present employment. This research gives implications on academic and economic policies. The university needs to anchor the curriculum evaluation measures to test the graduates' employability based on a competence model anchored in real-world work settings. The study highlights to conduct a tracer study
\end{abstract}


across the university with a focus on the job-specific skills of the graduates as per degree specialization and evaluate each specific major course based on the prospectus of the program to align MSU-GSC's course offerings to the needs of the industry.

Keywords: Relevance, Educational qualifications, Job mismatch, Tracer, Employability, Curriculum, Higher education

\section{Introduction}

The graduates have difficulty in finding and getting a job that rightfully match to their degree courses due to domineering factors brought about by the incongruence of educational qualification level and insufficient mastery of skills required for employment. Such reality suggests that universities have not fully prepared the graduates in skills training and that the curriculum is not relevant to the challenges in the modern global labor market (Adeyemo, Ogunleye, Oke, \& Adenle, 2010). "To ensure curriculum relevance, a curriculum is needed in which authentic practical work is the base, and subjects are integrated with students' practical work experience" (Hiim, 2017).

If the need for relevance in the curriculum is not met, graduates are then prompted to take a lengthy transition from the university to the labor market which leads to a long time looking for an appropriate job that matches their qualifications (Ho, 2015). The learning competencies are a loss on investment when graduates are unable to fit the degree, interests, and capabilities developed at a university to the demands of the labor market (Corominas, Saurina, \& Villar, 2010). This education-job mismatch is an important indicator of the performance of higher learning.

Based on the result of a survey of Capsada and Prades (2015), employers highly rate the shortage of applicants with the right skills $(60 \%)$ and graduates in a given field $(30 \%)$ as part of the difficulties in recruiting graduates, while Bachelor's degree is considered as an important factor in recruitment. Likewise, Eurobarometer (2010) reported the same shortage as part of the obstacle in filling in vacancies in Luxembourg (73\%), Germany, Austria and Norway (61\%-63\%), and Turkey (68\%).

Moreover, job mismatch postulates a major challenge to universities and labor markets in the Philippines (Baking, Quiambao, Cruz, Buenviaje, Nicdao, \& Nuqui, 2015). This prevailing situation is projected to widen the gaps between education and jobs in the industry (Medina, 2015) and an even important issue to deal with relative to economic (Jovović, Đurašković, \& Radović, 2017; Yusoff, Omar, \& Zaharim, 2013) and educational policies in the country. The employability skills of the graduates of higher education and the requirements needed in the present and future workplace should match in both environments (Abas \& Imam, 2016). Employers prefer to hire graduates who possess the qualifications that their company looks for during recruitment (Hodges \& Burchell, 2003).

As a solution to the situation, conducting a tracer study can provide information to improve academic, training, and employment policies and help graduates to decide on their education or career paths and grasp the needed skills in the labor workforce (Schomburg, 2016). Significant studies on graduate employment give a limited description of the professional success of graduates such that employment status serves as indicators for professional success (Adeyemo, 


\section{Macrothink}

Ogunleye, Oke, \& Adenle, 2010). These studies disregard the complexity of career plans and the employment factors that the graduates experience in the workplace.

These scenarios propelled for the conduct of this study that determined the relatedness of the educational qualifications and the curriculum of the graduates to their present work. This study specifically reported on the area of specialization of the graduates and their employment profile.

\subsection{Research Questions}

Changes have taken place over the last six years in the seven main fields of knowledge concerning the education-job match. This study analyzed the match between the educational qualification and curriculum of the graduates and their workplace. It has answered the following questions:

1). To what discipline and area of specializations do the graduates belong?

2). What is the employment profile of the graduates in their current work relative to:

2.1) Length to Land on the First Job

2.2) Employment Status

2.3) Monthly Income

2.4) Present Position

2.5) Type of Organization

2.6) Classification of Industry

3). What is the level of the match of the degree or field of study of the graduates to their employment?

4). What is the level of relevance of the curriculum of the graduates to their employment?

\section{Method}

A descriptive survey design was used in this study to determine the match of the educational qualifications and curriculum of the graduates to their current employment. It studied the inter-relationship between qualifications and work experiences of the graduates. The respondents of the study were from private and public employment sectors in SOCSARGEN which include South Cotabato, Sarangani, and General Santos City. This research was also part of a study in which the scope and the objectives were focused on the job satisfaction, job performance, and degree of fit and the level of match of the general employment skills, and personal attributes of the graduates such as teamwork, timeliness, diligence, among others.

\subsection{Respondents}

The study involved randomly selected graduates employed in various organizations in SOCSARGEN (South Cotabato, Sarangani, and General Santos City), Philippines. It included the graduates covering from batches 2012 to 2017 . It was difficult to trace the graduates of 
2012 to 2013, these graduates were holding positions with huge responsibilities in their respective organizations and cannot render their time to participate as respondents. However, those graduates who volunteered to answer the survey came from six academic batches: 2012 (9\% or 153$), 2013$ (10\% or 173$), 2014$ (16\% or 289$), 2015$ (20\% or 360$), 2016(26 \%$ or 289$)$, and $2017(19 \% 325)$. Out of 8,256 graduates, 1761 of them volunteered to participate in the tracer study. Table 1 shows the profile of the graduates.

The number of respondents who participated in this study consisted of $63 \%$ or 1101 females and $37 \%$ or 660 males who graduated from academic years 2012 to 2017 (Table 1). There are more female respondents than the male respondents who volunteered to participate in this tracer study. Further, the greater majority of MSU-GSC graduates are single (87\%) and only $12 \%$ are married since they are still in their prime age. The graduates are comprised of multicultural groups since MSU-GSC has a special mandate to provide quality education especially to Muslims and Indigenous People who belong to the cultural minority group. The zero percent in the ethnic affiliation explains there were only few graduates who participated since their population in the university is very small compared to the majority group (Cebuano and Ilonggo). However, they are given special privileges in the university such as lower-cut off scores in the entrance examination, among others. General Santos City is also predominantly composed of Cebuano and Ilongo tribes.

Table 1. Profile of MSU-GSC Graduates

\begin{tabular}{|c|c|c|c|c|c|}
\hline Gender & $\%$ & Ethnic Affiliation & $\%$ & Ethnic Affiliation & $\%$ \\
\hline Male & 37 & Aklanon & 1 & Mansaka & 0 \\
\hline Female & 63 & Bagobo & 0 & Samal & 1 \\
\hline Age & & Batangueno & 0 & Sangil & 0 \\
\hline $20-21$ & 4 & Bicolano & 0 & Subanen & 0 \\
\hline $22-23$ & 30 & B'laan & 3 & Surigaonon & 0 \\
\hline $24-25$ & 34 & Boholano & 1 & Tagakaulo & 0 \\
\hline $26-27$ & 21 & Cebuano & 37 & Tagalog & 1 \\
\hline $28-30$ & 8 & Ilocano & 4 & Tausug & 2 \\
\hline 31-above & 3 & Ilonggo & 28 & T'boli & 1 \\
\hline Civil Status & & Iranon & 0 & Tiruray & 1 \\
\hline
\end{tabular}




$\begin{array}{lcllll}\text { Single } & 87 & \text { Kalagan } & 0 & \text { Waray } & 0 \\ \text { Married } & 12 & \text { Kapampangan } & 0 & \text { Mixed Ethnicity } & 0 \\ \text { Separated } & 0 & \text { Maguindanaon } & 17 & \\ \text { Single Parent } & 1 & \text { Mandaya } & 1 & \\ \text { Widower } & 0 & \text { Manobo } & 0 & \end{array}$

*Zero percent indicates that there are less than 8 individuals for each choice.

Hence, MSU-GSC Graduates are accustomed to the different cultures which is an advantage for the graduates since they can deal with people from other tribes having different cultural background in the workplace. Contrary to this, Nagarajan and Jenny Edwards (2014) stated that cultural awareness and ability to work with cultures is a vital skill but which was lacking in their graduates' attributes.

The detail of the professional eligibilities of MSU-GSC graduates having their degree-related licenses is presented in Table 2. The graduates acquired licenses related to their courses, Civil Service (CS) professional licenses, and other board examination licenses. Majority of the graduates are licensed professionals whether related to their degree or a general license such as the Civil Service Professional.

Mindanao State University-General Santos City has seven colleges and the graduates were representatives of each college, namely: agriculture (COA), business administration and accountancy (CBAA), engineering (COE), fisheries (COF), education (COE), social sciences and humanities (CSSH), and natural sciences and mathematics (CNSM).

Table 2. Professional Licenses of the MSU-GSC Graduates

\begin{tabular}{llllll}
\hline \multirow{2}{*}{ Colleges } & Degree License or with CS & $\begin{array}{l}\text { RPT \& } \\
\text { CS }\end{array}$ & $\begin{array}{l}\text { No } \\
\text { Response }\end{array}$ & Total \\
\hline \multirow{2}{*}{ Registered Agriculturist } & $25 \%$ & & \\
\cline { 2 - 3 } & Registered Agriculturist with CS & $14 \%$ & & & \\
\cline { 2 - 3 } & Engineer with CS & $13 \%$ & $25 \%$ & $100 \%$ \\
\cline { 2 - 3 } & Registered Engineer & $19 \%$ & & \\
\hline
\end{tabular}


CBAA Certified Public Accountant with CS $\quad 27 \% \quad 1 \% \quad 35 \% \quad 37 \% \quad 100 \%$

\begin{tabular}{|c|c|c|c|c|c|c|}
\hline COED & Registered Professional Teacher & $57 \%$ & $39 \%$ & $2 \%$ & $2 \%$ & $100 \%$ \\
\hline \multirow{2}{*}{ COE } & Registered Engineer with CS & $40 \%$ & \multirow{2}{*}{$1 \%$} & \multirow{2}{*}{$4 \%$} & \multirow{2}{*}{$7 \%$} & \multirow{2}{*}{$100 \%$} \\
\hline & Registered Engineer & $48 \%$ & & & & \\
\hline \multirow{3}{*}{$\mathrm{COF}$} & Fisheries Technologist & $23 \%$ & \multirow{3}{*}{$0 \%$} & \multirow{3}{*}{$19 \%$} & \multirow{3}{*}{$49 \%$} & \multirow{3}{*}{$100 \%$} \\
\hline & Fisheries Technologist with CS & $8 \%$ & & & & \\
\hline & Registered Professional Teacher & $1 \%$ & & & & \\
\hline \multirow{2}{*}{ CNSM } & Medical Doctor with CS & $1 \%$ & \multirow{2}{*}{$22 \%$} & \multirow{2}{*}{$43 \%$} & \multirow{2}{*}{$33 \%$} & \multirow{2}{*}{$100 \%$} \\
\hline & Registered Nurse with CS & $1 \%$ & & & & \\
\hline CSSH & Registered Professional Teacher & $30 \%$ & $16 \%$ & $18 \%$ & $36 \%$ & $100 \%$ \\
\hline
\end{tabular}

Legend: RPT (Registered Professional Teacher); CS (Civil Service Professional License).

\subsection{Instruments}

The researcher designed a five-page questionnaire as an instrument of the study. Experts validated the questionnaires which were tested thereafter to ensure the reliability of the said questionnaires. The experts were composed of a principal and faculty of the graduate school of MSU-GSC, a full-fledged professor from the same university, a specialist from the Department of Trade and Industry, and a guidance counsellor from the public employment organization. All the validators are research degree holders. Moreover, the paper-based instrument was administered in the different offices where the graduates are employed. An online version of the questionnaire was also given to the graduates who were accessible through their Facebook accounts.

\subsection{Data Collection}

After field testing for the reliability of the designed survey questionnaires, the researchers gathered the actual data by going to different organizations and asking for the approval of heads of the respective offices. The instruments were also made available online to reach the graduates even in the farthest location of SOCSARGEN. The online version of the instrument was accessible in Facebook that woud open in a Google form. Confidentiality of the data was adhered to and ethical standards were followed by obtaining a filled consent form before answering the instrument. Approval was obtained from the Institutional Ethics Review Board 


\section{Macrothink}

International Research in Education

ISSN 2327-5499

2021, Vol. 9, No. 1

before the conduct of the study. The survey was conducted within a period of ten months which started from August 2018 until May 2019.

\subsection{Data Analysis}

The present study delved into an an analysis of the educational qualifications and job match among the graduates of the university. Descriptive statistics such as frequency, mean, and percentage were applied as treatments.

\section{Results and Discussion}

There were 1, 761 graduates who gave their feedback regarding their qualifications which they acquired from the university concerning the degree of match of the curriculum to their job. The educational qualifications of the graduates helped them land careers and acquire stable jobs in the industry. Majority of the graduates only have Bachelor's degree as their highest educational attainment (92\%) while only 7\% (161 respondents) of them have their master's degree and 1\% (10 respondents) earned their doctoral degrees. Very few of the respondents are post-graduate degree holders. This reality can be attributed to the lack of offerings of masteral and doctoral degrees from colleges and universities related to their bachelor's degree courses in SOCSARGEN Area.

An example for this is the lack of courses in graduate studies aligned to Agriculture, Accountancy, Natural Sciences and Mathematics, Fisheries, and Engineering. Majority of those who acquired their master's degree are graduates from the College of Education since the graduate courses are offered in the said location.

Table 3. Area of specializations of the graduates from the seven colleges

\begin{tabular}{llll}
\hline Colleges & $\mathbf{\%}$ & Colleges & $\mathbf{\%}$ \\
\hline Social Science \& Humanities & $\mathbf{2 3 \%}$ & Agriculture & $\mathbf{1 5 \%}$ \\
AB English & 5 & BS Agricultural Busi. Man. & 2 \\
AB Filipino & 8 & BS Agricultural Eng. & 6 \\
AB History & 3 & BSA Agronomy & 5 \\
AB Islamic Studies & 3 & BSA Animal Science & 2 \\
AB Political Science & 3 & & \\
AB Sociology & 2 & & \\
Engineering & $\mathbf{9 \%}$ & Bus. Admin \& Accountancy & $\mathbf{1 0 \%}$ \\
BS Civil Engineering & 2 & BS Accountancy & 4 \\
BS Electrical Eng. & 2 & BS in Business Economics & 3 \\
BS Elec. \& Comm. Eng. & 2 & BSBA Entrep. Marketing & 1 \\
BS Mech. Eng. & 3 & BSBA Management & 3
\end{tabular}


Fisheries

BS Fisheries

BS Marine Biology

Natural Sciences \& Math

BS Biology

BS Information Tech. 2

BS Mathematics

5
2021, Vol. 9, No. 1

7\% Education

$26 \%$

BEED General Education

18

BSED Biology

3

$10 \%$

BSED English

2

BSED Filipino

1

BSED Mathematics

The graduates belong to various fields of study with different area of specializations (see Table 3). Mindanao State University-General Santos City caters seven colleges. Graduates from the College of Education constituted 26\% of the graduates. Majority of these were from the Bachelor of Elementary Education (BEED) specializing in General Education. On the other hand, the Bachelor of Secondary Education major in Biology, English, Mathematics, and Filipino have nearly similar share.

Furthermore, $23 \%$ of the respondents were from the College of Social Sciences and Humanities. Representatives from the said college were composed of $8 \%$ respondents specialized Bachelor of Arts (AB) in Filipino and 5\% of respondents specialized AB English.

About $15 \%$ of the respondents were from the College of Agriculture. Specifically, those graduates specialized Bachelor of Science (BS) in Agricultural Engineering (6\%), Bachelor of Science in Agriculture (BSA) Agronomy (5\%), BSA Animal Science (2\%), and BS Agricultural Business Management (2\%).

Graduates from the College of Business Administration and Accountancy comprised 10\% of the total respondents with an area of specialization in BS Accountancy, BS Business Economics, BSBA Management, and BS Entrepreneurial Marketing. It constituted of 10\% from the College of Natural Sciences and Mathematics who specialized in BS Mathematics, BS Biology, and BS Information Technology. Lastly, 9\% of the respondents were graduates of the College of Engineering. They specialized in BS Mechanical Engineering, BS Civil Engineering, BS Electrical Engineering, and BS, Electronics and Communications Engineering. Seven percent of graduates were from the College of Fisheries who specialized in BS Fisheries and BS Marine Biology.

The respondents of a tracer study also came from different academic majors such that $27 \%$ majored in agriculture, $27 \%$ in education and social sciences, $20 \%$ in construction and engineering, and $26 \%$ in business (Ho, 2015). Evidence from surveys stated that career-specific and generalist degrees can produce employability outcomes among the graduates (Kinash et al., 2014).

This study also traced the employment profile of its graduates for the academic institution to provide for the needs of manpower in the industry. The graduates were asked about the waiting period for them to acquire their first job after graduating from the university. 
It can be noted (Figure 1) that 24\% (425 persons) of the graduates obtained their first job in less than a month after graduation. Also, 20\% (357) of the graduates were hired in a span of 2 to 3 months after graduation. In less than a year after graduation (seven to eleven months), $12 \%$ (208) graduates got hired in a job.

However, 17\% (301) of the respondents said that they acquired their first job after one to two years of graduating from the university and 3\% (60) landed their first job after 2 to 3 years, and one percent (18) in three to four years. Among those graduates who obtained their first job after 1 to 2 years of graduation from MSU-GSC were mostly from the batches of 2015 to 2017. A significant share (17\%) of graduates obtained their first job within a year or so after graduating from college. These graduates are distributed discretely within six years of academic classes. At present, the majority of these graduates who took their first job after two years of graduating from MSU-GSC were employed in the Education Industry and working for the National Government as part of the teaching workforce of the country.

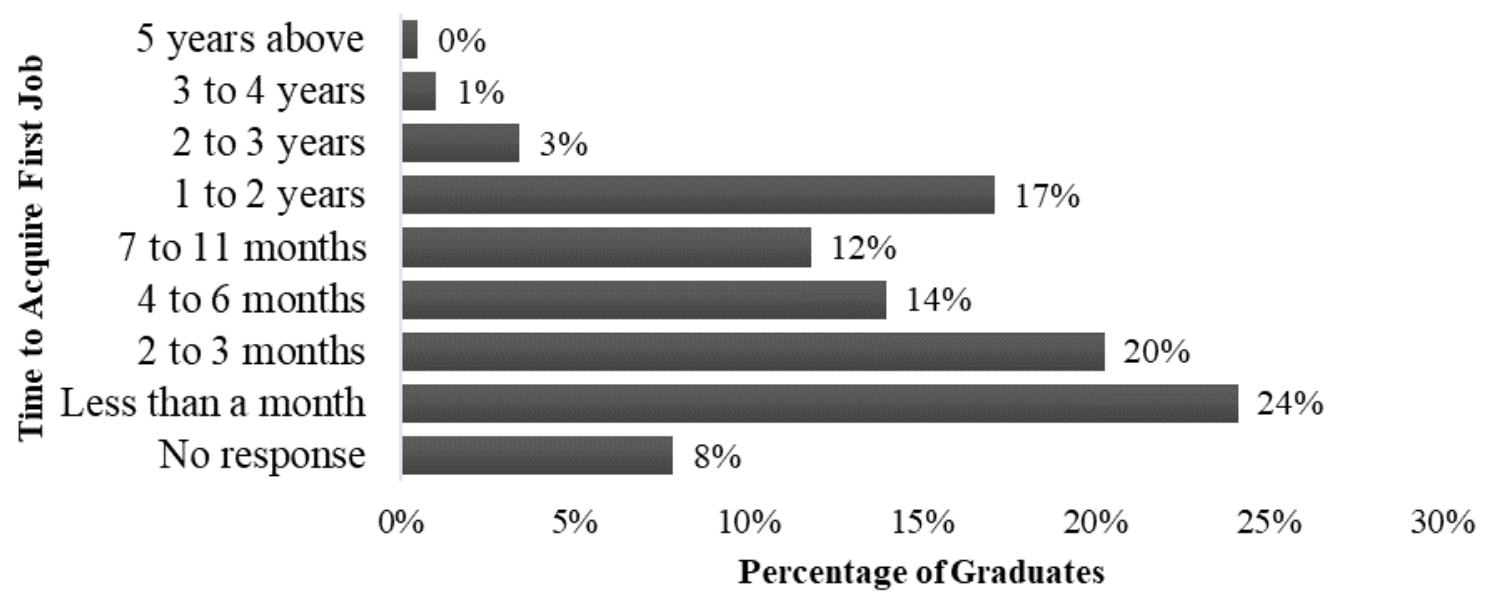

Figure 1. Length of time for MSU-GSC graduates to land on their first employment

The data shows that more than half of the graduates obtained their first job in less than 6 months after graduating from college. Similarly, out of 710 graduates (respondents) from 13 academic programs, $83.80 \%$ found jobs right after graduation, and $12.11 \%$ land a job in less than a year (Gines, 2014). However, this current study has better transition result from the university to the workplace than the result of the study of the National Commission for Further and Higher Education (2016) where 47\% of graduates had found employment in the first 12 months after completion of studies and around $22 \%$ obtained it within one or two years.

Figure 2 shows the employment status of MSU-GSC graduates. It shows that more than half of the graduates (61\% or 1067 respondents) hold permanent positions while $19 \%$ (328 persons) were employed on a contractual basis. Unemployed consisted of 7\% (125 respondents) while self-employed formed only one percent (24 respondents). 


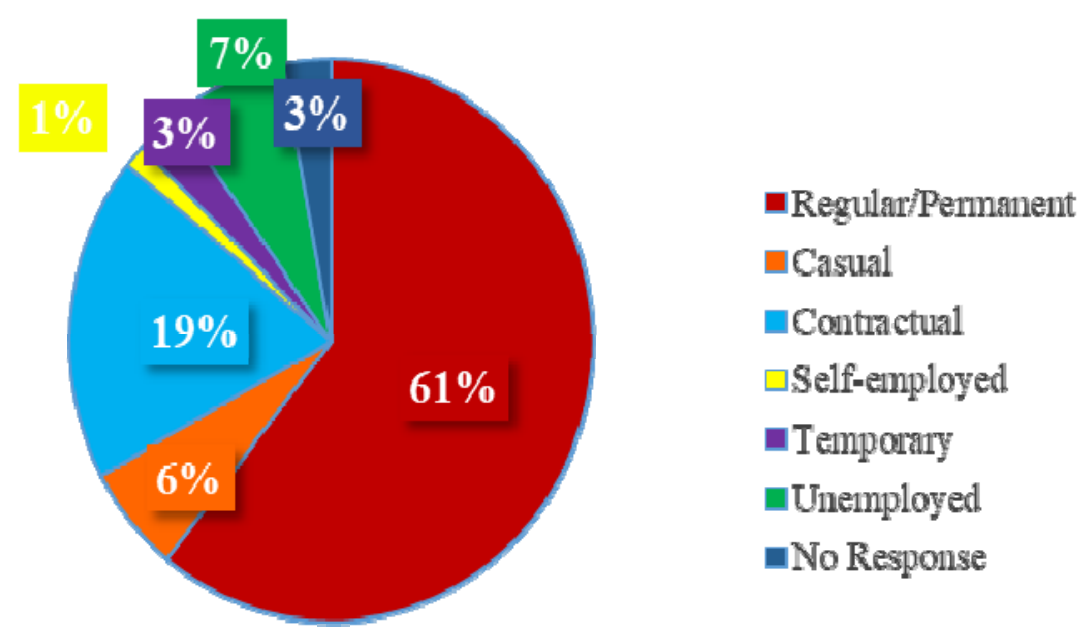

Figure 2. Employment status of MSU-GSC graduates

It is clear from the result that out of 1761 sampled MSU-GSC graduates, $92 \%$ of them are employed in an organization while 8\% (149) respondents (including the self-employed) are not working in an organization.

Out of the 149 graduates who are not working in an organization or choose to be self-employed, $32 \%$ stated that they are not seeking for work because of advance or further study while $16 \%$ of them did not seek for a job. Likewise, $12 \%$ of them decided not to find a job due to family concerns and $4 \%$ did not find for a job owing to health-related reasons. Among these graduates, $16 \%$ expressed that there is no job opportunity and $7 \%$ stated that they lack work experience so they remain unemployed. The remaining $9 \%$ did not seek for work because of other reasons.

Some of the other reasons from the graduates who are unemployed included: "just resigned from the previous job, currently waiting for application results as registered qualified applicants from DepEd [Department of Education], have an online business, preferred freelancing," and one respondent said that "it was hard to find a job aligned to one's degree," and another unemployed graduate admitted of having "resigned the last job to look for another which suits my credentials."

Though many of the graduates hold permanent positions, others who hold temporary positions can be explained by the study of Kiliswa, Udoto, and Konyango (2016) who confirmed that the expected age bracket for permanent employment is 30 years of age after going through four years in the University.

The monthly remuneration of the graduates is presented on Figure 3 . There are only $5 \%(81)$ of graduates who earn a monthly salary of P35, 000.00 and above. Most graduates earn a monthly salary of P20, 000.00 to P25, 000.00 (30\%) and P15, 000.00 to less than P20, 000.00 $(20 \%)$. However, twelve percent (12\%) earn a monthly salary below P10, 000.00. There are also $9 \%$ of graduates who did not respond since there are graduates who have not worked in 
an organization.

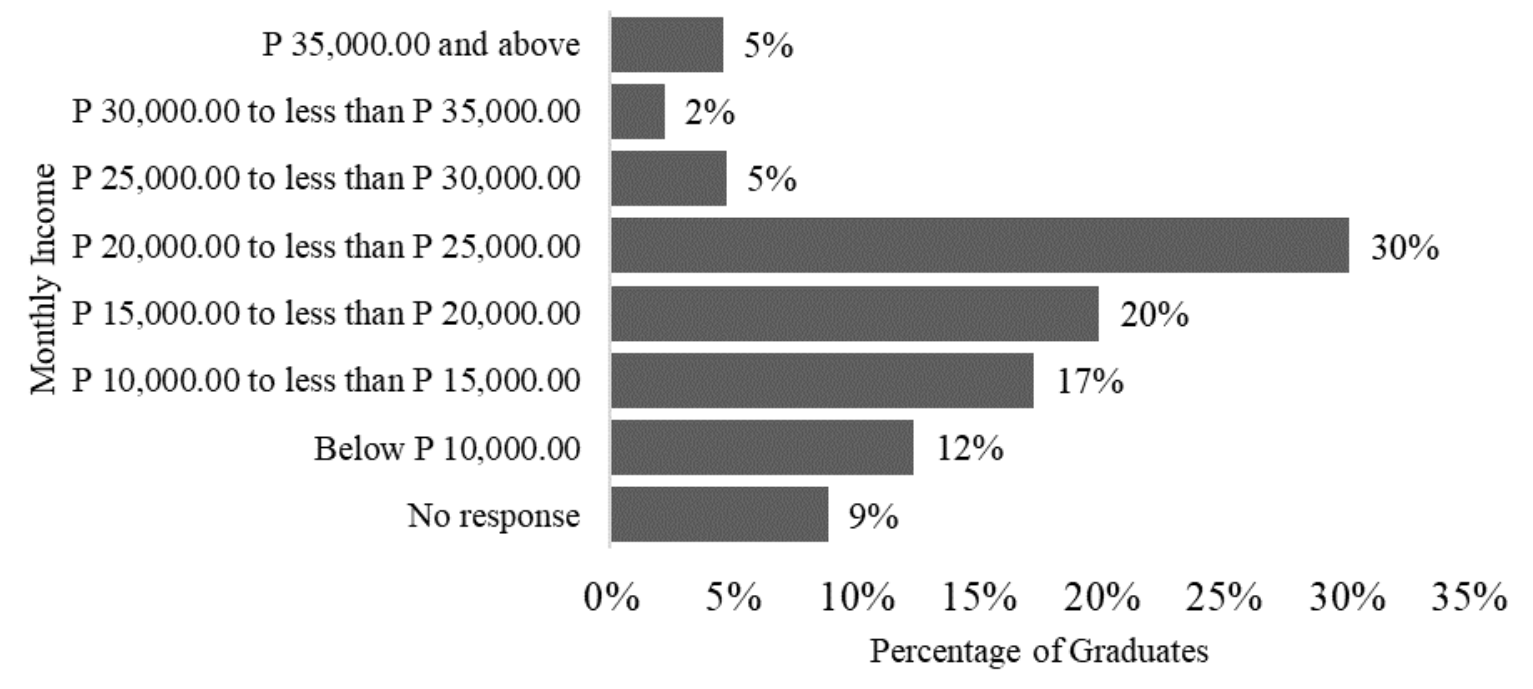

Figure 3. Monthly income of MSU-GSC graduates

The data indicates that nearly half of the graduate employees earn a gross monthly income between P10, 000.00 to $\mathrm{P} 20,000.00$ which is the average wage that employees can commonly earn while working in companies or organizations. More than one-fourth of the number of employees earn a higher salary than the average wage. While, high-income earners were those few graduates who earn more than P35, 000.00 per month.

Similarly, Baking et al. (2015) reported the income of their graduates that ranged from below P $10,000.00$ to P $30,000.00$ and higher with the mean monthly income of P 18, 1900.47. Whilst, the greater majority of their graduates earn a gross monthly income from $\mathrm{P} 10,000.00$ to $\mathrm{P} 25,000.00$.

The next figure shows the current position levels that graduates hold in their respective organizations (Figure 4). The graduates have a series of jobs before their current jobs and varied position levels thereby. But after years of graduating from the university and varied roles in previous organizations, they now have acquired work experiences that paved the way for them to be given relevant position levels. 


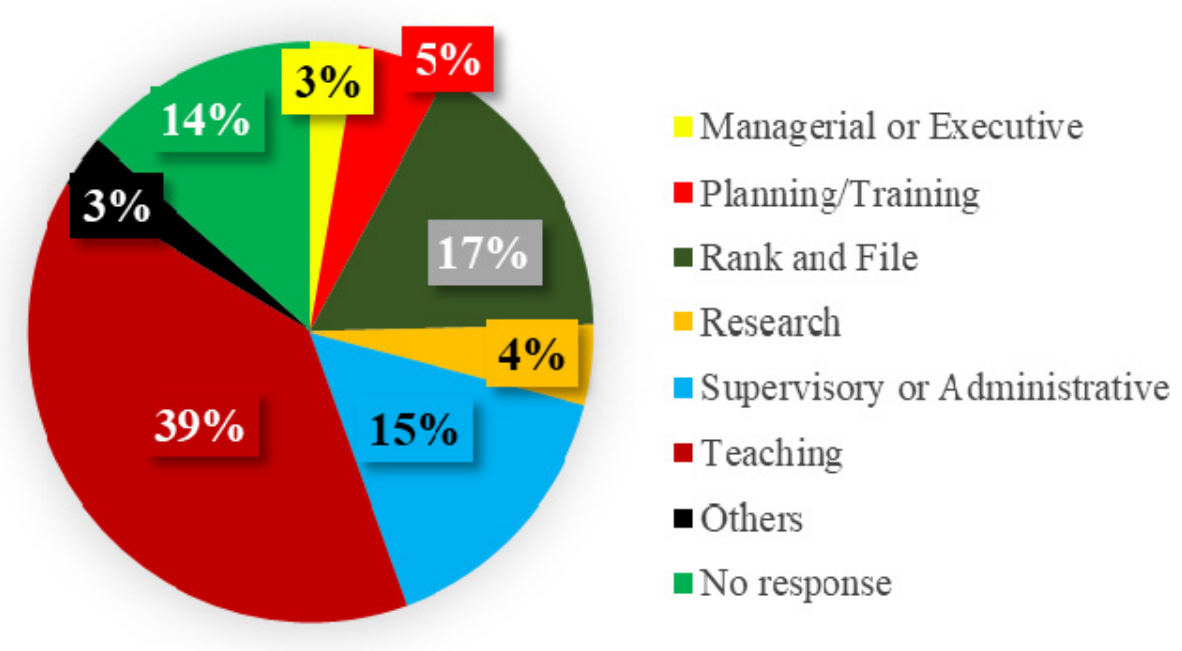

Figure 4. Present position level of MSU-GSC graduates

There are only 3\% (48) of graduates who are at the managerial or executive position level. There are $39 \%$ (688) of the graduates who are into teaching. There are some graduates from different colleges that took the Licensure Examination for Teachers and are thereby licensed as Registered Professional Teachers upon passing the said examination. This explains that aside from the graduates of the College of Education, there are graduates of other colleges who also went into the teaching profession such as the graduates of CSSH and CNSM among others.

Also, $15 \%$ of graduates acquired company positions as supervisory or administrative and rank and file employees which make up $17 \%$ of graduates). There are $5 \%$ of graduates who have positions related to planning and training, $4 \%$ are into researching, while $14 \%$ of graduates are classified into other occupations.

The data indicates that more than one-fourth of the number of MSU-GSC graduates worked in teaching position levels and as regular position employees. There are those few graduates who also who worked in the technical areas such as research, planning, and training and those very few graduates who are having positions as supervisory or administrative and managerial or executive positions in their organizations.

Moreover, MSU-GSC graduates are currently working in different types of legal organizations (see Figure 5). There are 39\% (628) graduates who are working for the National Government, 25\% (407) are affiliated in the Private/Stock Corporation and 10\% (159) employees are currently working in a local city government. 


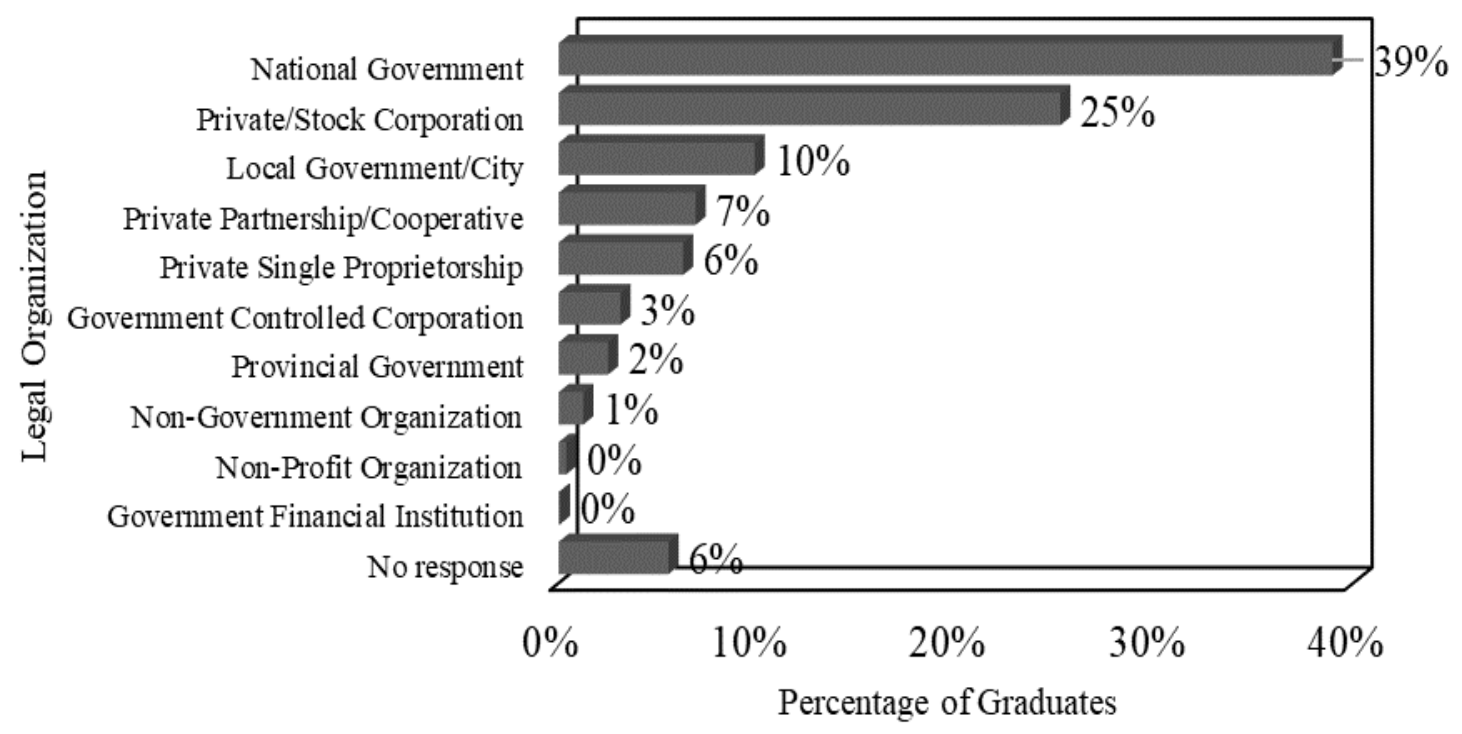

Figure 5. Type of legal organization where MSU-GSC graduates belong

The result shows that more than $50 \%$ of the graduates are affiliated in a government type of organization while the remaining graduates are affiliated in private organizations. There are $6 \%$ who are working either in private or government entities.

In contrast, a study (Loquias, 2015) revealed that $62 \%$ graduates were employed in private companies, only $11 \%$ worked in government service, $2 \%$ were self-employed and $1 \%$ worked in a semiprivate or, semi-government establishment but this can be attributed to the nature of the jobs of the graduates since the respondents were Electronics Engineering graduates.

The graduates are employed in a different classification of industry (see Figure 6). In the Education Industry, $41 \%$ of employees are working while some are in Agriculture and Forestry (13\%) and some are in manufacturing (6\%), administrative and support services (5\%), and professional scientific and technical activities (5\%). It can be gleaned from the data that the graduates are employed in various industries but the majority are working in the Education Industry.

The result shows that graduates of MSU-GSC are spread into different classifications of industries. There are very few graduates, although not significant in terms of percentage share but who are employed in arts, entertainment, and recreation, mining and quarrying, and public safety. About $4 \%$ of graduates worked in other category of industries. 


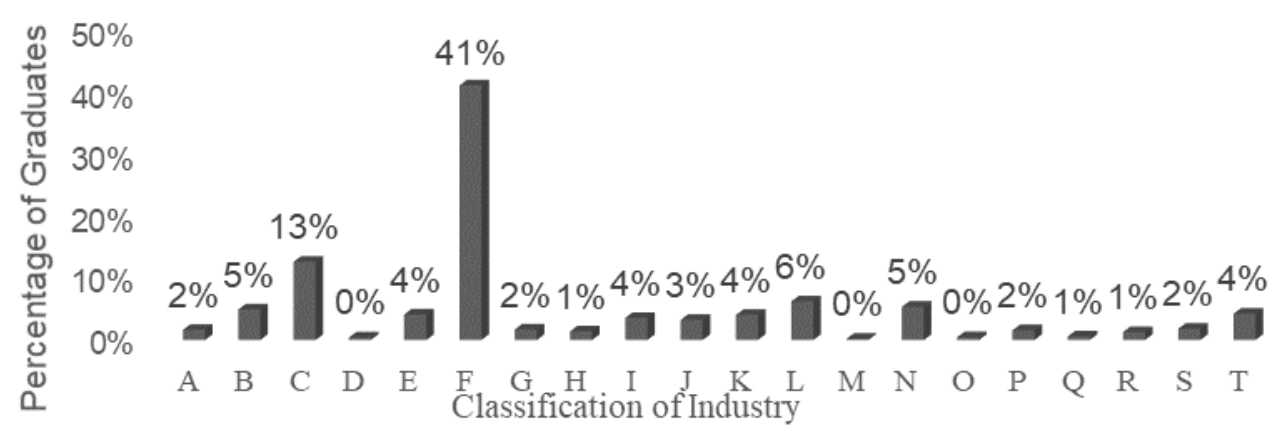

$\begin{array}{ll}\text { A } & \text { Accommodation and Food Services } \\ \text { B } & \text { Administrative and Support Services } \\ \text { C } & \text { Agriculture and Forestry| } \\ \text { D } & \text { Arts, Entertainment and Recreation } \\ \text { E } & \text { Construction } \\ \text { F } & \text { Education } \\ \text { G } & \text { Electricity, Gas and Steam and Air Conditioning Supply } \\ \text { H } & \text { Extra-territorial Organization and Bodies (Fishing) } \\ \text { I } & \text { Financial and Insurance Activities } \\ \text { J } & \text { Human Health and Social Work Activities }\end{array}$

Figure 6. Classification of industry of MSU-GSC graduates
$\mathrm{K}$ Information and Communication

L Manufacturing

M Mining and Quarrying

N Professional, Scientific and Technical Activities

O Public Safety

P Real Estate, Renting and Business Activities

Q Transport and Storage

R Water Supply, Sewerage, Waste Management \& Remediation Activities

S Wholesale and Retail Trade; Repair of Motor Vehicles and Motorcycles $\mathrm{T}$ No response

Figure 7 presents the assessment of the degree of the graduates to match the field of study they took to their current employment. The results revealed that $34 \%$ of the graduates rated their degree as very highly matched to their present job. Further, $28 \%$ of the graduates rated their degree as highly matched to their present job and $24 \%$ assessed that their degree is moderately matched to their present job.

On the other hand, few of the graduates $(6 \%)$ assessed their degree as less matched, and very few (4\%) of the graduates rated their degree as least matched to their present job. Only $1 \%$ of the graduates remains neutral on it.

Those graduates who rated less and less matched are currently working in different fields as senior environmental management specialist, community relations supervisor, development worker, encoder, graphic designer, administrative assistant, document record controller, sales, online English teacher, account operations specialist, freelance cultural worker, fireman, and policeman, etc. Some graduates who were not Education degree holders also went into the teaching field since many took the LET based on their professional eligibility. There were also graduates whose field of specialization did not match with the available job. However, based on the data above, this implies that more than half of the graduates' specializations were highly aligned to their present employment. 


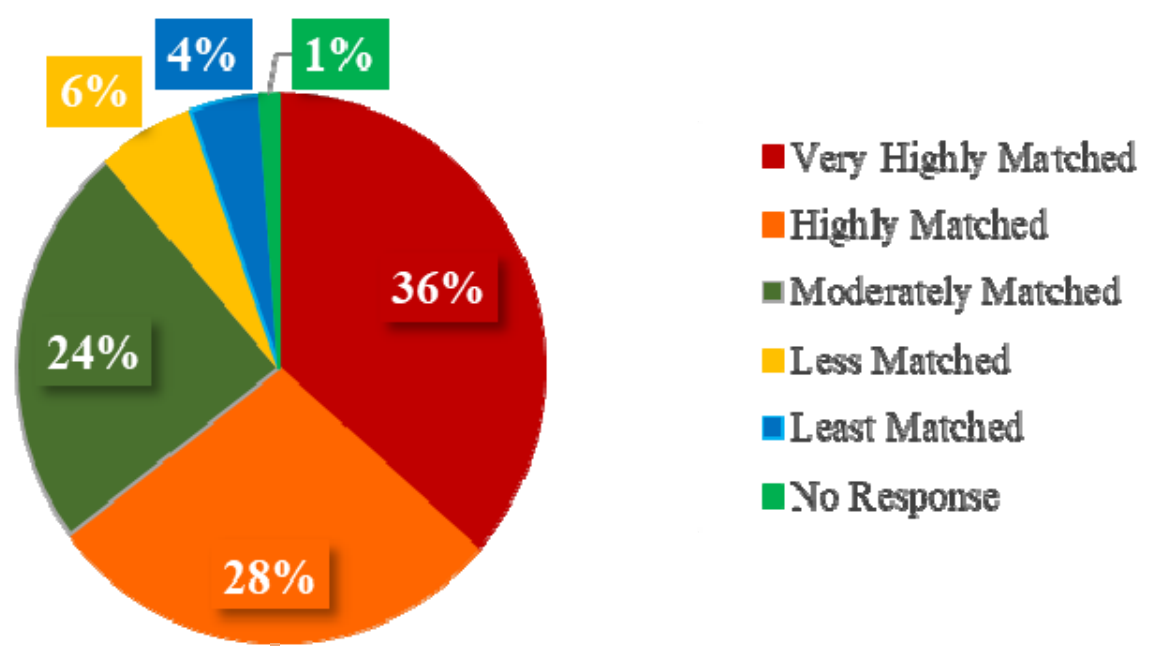

Figure 7. Match of the degree of the graduates to their present job

A study admitted that there was a degree of the underutilization of skills among the graduates (Aquino, Punongbayan, Macalaguim, Bauyon, Rodriguez, \& Quizon, 2016). Though there was a high proportion of employment about their college degree, 30 to $32 \%$ of graduates said that their jobs were not aligned to their degree specialization. Despite acquirement of unrelated college education, these graduates engaged in some kind of job for a living.

The graduates also assessed the relevance of the curriculum to their present job. The figure shows that $35 \%$ of graduates assessed that the curriculum they had was highly relevant to their job (see Figure 8). Also, 28\% evaluated that the curriculum was very highly relevant while $26 \%$ of graduates rated that it was moderately relevant to their present job.

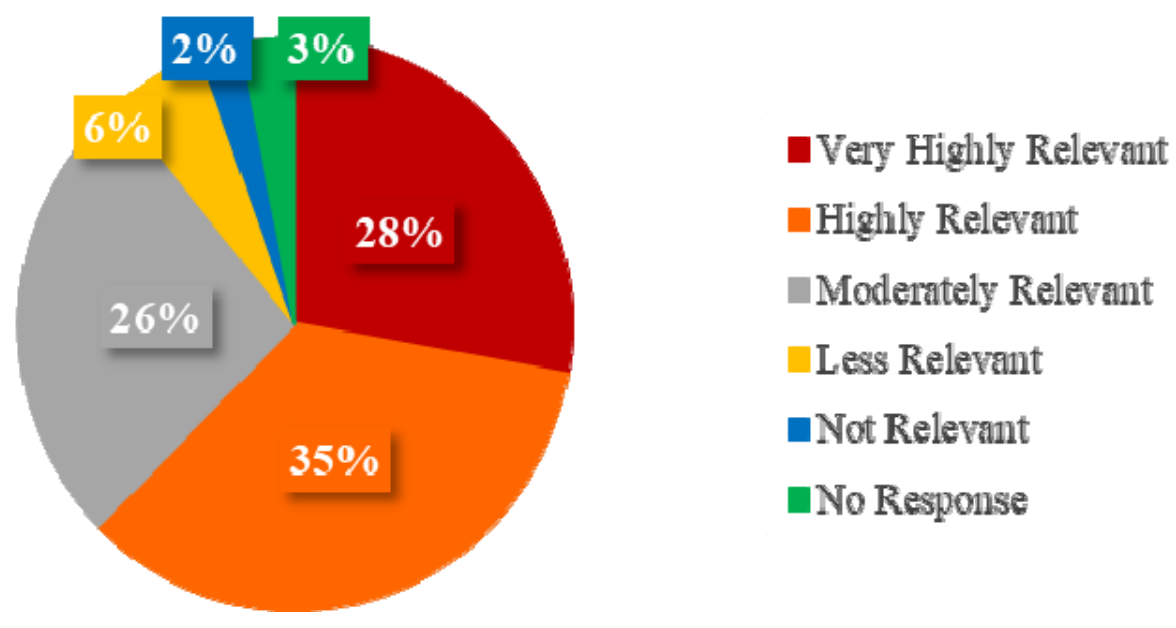

Figure 8 . The relevance of the curriculum of the graduates to their present job 
However, $6 \%$ graduates assessed that the curriculum they took was less relevant and $2 \%$ of graduates who answered that it was not relevant at all. The 3\% graduates remained neutral. This non-relevance of the curriculum is attributed to the graduates whose present jobs are not related to their discipline. However, many graduates have jobs that are aligned to their degree. Thus, the result implies that more than half of the graduates rated their curriculum as highly relevant to their present jobs.

In a similar study, Kiliswa, Udoto, and Konyango (2016) asked the respondents to rate the appropriateness of the curriculum to their career placement. Out of the 78 courses that were offered during their four-year study, $72.54 \%$ were rated most useful, $18.91 \%$ were useful while $5.82 \%$ were not useful and $1.09 \%$ not useful.

A study (Baking et. al, 2015) also reported the employability of the 630 graduates who were randomly selected from three colleges in different programs for policy formulation and curricular enhancement. The result revealed that these graduates are highly employable, and a great majority have jobs aligned to their university training. They were highly productive and have the readiness in meeting the job requirements.

\section{Limitations and Implications}

This study has its limitations such that the results are based on the self-assessment of the graduates and no actual tests have been done to analyze the curriculum based on the curricular evaluation models. Likewise, there was only a small number of graduates who volunteered from different colleges which cannot be generalized to the entire population of the university. Nonetheless, this research gives implications on academic and economic policies. The university needs to anchor its curriculum evaluation measures on a competence model anchored in the real context of the industries for further curriculum enhancement. Findings of a study revealed that the universities need to give opportunities so that students can engage themselves in meaningful work while simultaneously learning based on their respective degrees (Kinash et al., 2014).

Economically, the employers should also establish an effective labor market information centers linked to the career counseling of the universities (Adeyemo, Ogunleye, Oke, \& Adenle, 2010). This effort can allow for curriculum consultations and recruitment policies to be disseminated to the universities to attract proficient and skilled graduates as employees. To fulfil the graduates' need for post-graduate studies, the university can offer courses aligned to their degree. Future research should also focus on conducting a university-wide tracer study that highlights the job-specific skills of the graduates per program and a specific area of specialization. Employers' performance ratings of their employees should also be considered for investigation.

\section{Conclusion}

Matching the education system to the labor market means economic profitability and growth so the institutions should mitigate the disturbance in the economy (Jovović, Đurašković, \& Radović, 2017). As such, this study endeavored to determine the match of the educational qualifications of the graduates and the relevance of the curricular offerings of MSU-GSC to 
meet the needs in the context of the work environment.

Data show that most of the graduates found their first job in less than six months after graduating from college. Majority of graduates were employed in government and private organizations. More than one-fourth of the graduates have teaching positions and are regular employees while the other graduates are in the technical areas such as research, planning, and training, while a few graduates are into supervisory and executive positions in the said organizations. Majority of them also rated that their degree of specialization is highly matched and that the curriculum is highly relevant for their current job.

However, it should be taken into account that there are few graduates who rated that their degrees and curriculum do not fit the needed competencies in the workplace. Part of the chief issues linked to graduate employability is related to mismatch between graduate competences and employer needs (Abelha et al., 2020). A study emphasized that not all the categories under employability skills that target the educational qualifications can be relevant to the graduates for their performance in the place of employment (Abas \& Imam, 2016). The qualifications are higher for some jobs and the graduates' early career credentials may not match the demands of the position.

Moreover, MSU-GSC graduates are spread into different classifications of industries following their field of specializations. Findings indicate the educational qualifications of the graduates or their field of specializations are aligned to the requirements in the workplace since they are also employed in their respective industries. Based on the graduates' ratings, they are highly employable and their university training is aligned to the job requirements. The training of the university provided through their curriculum indicates transferability of the theoretical knowledge and practical skills for the graduates to perform their jobs according to the demands in the work environment. Hence, MSU-GSC graduates' obtained a relevant curriculum from the university. Their educational profile and learning outcomes gained from the degree contribute to the demands in the industry.

\section{Acknowledgments}

This research was funded by Mindanao State University-General Santos City, Philippines through the Vice Chancellor for Research and Extension, Dr. Edna P. Oconer. The authors would like thank the alumni 2012 to 2017 of the said university for voluntarily giving their time to serve as respondents of this study. The authors would also like to acknowledge the student enumerators from different colleges of the said university for giving out their time and efforts to assist the researchers during the data collection.

\section{References}

Abas, M., \& Imam, O. (2016). Graduates' Competence on Employability Skills and Job Performance. International Journal of Evaluation and Research in Education, 5(2), 119-125. https://doi.org/10.11591/ijere.v5i2.4530

Abelha, M., Fernandes, S., Mesquita, D., Seabra, F. \& Ferreira-Oliveira, A.T. (2020). Graduate Employability and Competence Development in Higher Education-A Systematic 
Literature Review Using PRISMA. Sustainability, 12(5900), 1-27. https://doi.org/ $10.3390 /$ su12155900

Adeyemo, S. A., Ogunleye, A. O., Oke, C. O., \& Adenle, S. O. (2010). A survey of factors determining the employability of science and technology graduates of polytechnics and universities in the Nigerian labour market. Journal of Science and Technology Education Research, 1(5), 99-106.

Capsada, Q., \& Prades, A. (2015). Employers' Perceptions of the Employability and Skills of Recent Graduates in Catalonia. Main findings of the AQU Catalunya Employers Survey.

Aquino, A., Punongbayan, E., Macalaguim, L., Bauyon, S., Rodriguez, R., \& Quizon, G. (2016). Teacher Education Graduate Tracer Study from 2010 to 2014 in One State University in Batangas, Philippines. Asia Pacific Journal of Multidisciplinary Research, 3(5), 45-50.

Baking, E. G., Quiambao, D. T., Cruz, R. C., Buenviaje, L. M. B., Nicdao, R. C., \& Nuqui, A. V. (2015). Employability and productivity of graduates: an exploratory analysis of program strengths and weaknesses. Journal of Economic Research, 1(1), 1-10.

Corominas, E., Saurina, C., \& Villar, E. (2010). The Match between University Education and Graduate Labour Market Outcomes (Education-Job Match): An analysis of three graduate cohorts in Catalonia.

EU Barometer (2013). Employers' perception of graduate employability. Analytical Report," Flash Eurobarometer 304,

Gines, A. C. (2014). Tracer Study of PNU Graduates. American International Journal of Contemporary Research, 4(3).

Hiim, H. (2017). Ensuring Curriculum Relevance in Vocational Education and Training: Epistemological Perspectives in a Curriculum Research Project. International Journal for Research in Vocational Education and Training (IJRVET), 4(1), 1-19. https://doi.org/ 10.13152/IJRVET.4.1.1

Ho, H. (2015). Matching University Graduates' Competences with Employers' Needs in Taiwan. International Education Studies, 8(4). https://doi.org/10.5539/ies.v8n4p122

Hodges, D., \& Burchell, N. (2003). Business Graduate Competencies: Employers' Views on Importance and Performance. Asia-Pacific Journal of Cooperative Education, 4(2), 16-22.

Jovović, M., Đurašković, J., \& Radović, M. (2017). The Mismatch between the Labour Market and the Education System in Montenegro: Implications and Possible Solutions. Informatologia, 50(1-2), 22-37.

Kiliswa, I., Udoto, M., \& Konyango, J. (2016). Tracer Study of Bachelor of Science in Agricultural Education and Extension Graduates -Class of 2008 - Egerton University. Imperial Journal of Interdisciplinary Research, 2(8).

Kinash, S., Crane, L., Knight, C., Dowling, D., Mitchell, K., McLean, M., \& Schulz, M. (2014). Global graduate employability research: A report to the Business20 Human Capital 
Taskforce (DRAFT). Gold Coast, QLD Australia: Bond University.

Loquias, R. (2015). Employability of the Bachelor of Science in Electronics Engineering Graduates of Camarines Sur Polytechnic Colleges. Asia Pacific Journal of Multidisciplinary Research, 3(4), 33-40.

Medina, M. (2015). Gender and educational influences of job mismatch: The Case of Forestry and Environmental Science Graduates of a Philippine State University. Journal of Environmental and Occupational Science, 4(1), 5-9. https://doi.org/10.5455/jeos.2014112 5075125

Schomburg, H. (2016). Carrying out tracer studies - Guide to anticipating and matching skills and jobs, 6 .

Yusoff, Y. M., Omar, M. Z., \& Zaharim, A. (2013). Evaluation of Graduates' Performance using Fuzzy Approach. Procedia - Social and Behavioral Sciences, 102, 64-73. https://doi.org/10.1016/j.sbspro.2013.10.714

\section{Copyright Disclaimer}

Copyright reserved by the authors.

This article is an open-access article distributed under the terms and conditions of the Creative Commons Attribution license (http://creativecommons.org/licenses/by/4.0/). 